\title{
Recent Advances in Soil Moisture Estimation from Remote Sensing
}

\author{
Jian Peng ${ }^{1,2, *}$ (D) and Alexander Loew ${ }^{1,2}$ \\ 1 Department of Geography, Ludwig-Maximilians Universität München, Munich, 80333, Germany; \\ alexander.loew@lmu.de \\ 2 Max Planck Institute for Meteorology, Hamburg, 20146, Germany \\ * Correspondence: jian.peng@mpimet.mpg.de; Tel.: +49-89-2180-6515
}

Received: 9 June 2017; Accepted: 13 July 2017; Published: 16 July 2017

\begin{abstract}
Monitoring soil moisture dynamics from local to global scales is essential for a wide range of applications. The field of remote sensing of soil moisture has expanded greatly and the first dedicated soil moisture satellite missions (SMOS, SMAP) were launched, and new missions, such as SENTINEL-1 provide long-term perspectives for land surface monitoring. This special issue aims to summarize the recent advances in soil moisture estimation from remote sensing, including recent advances in retrieval algorithms, validation, and applications of satellite-based soil moisture products. Contributions in this special issue exploit the estimation of soil moisture from both microwave remote sensing data and thermal infrared information. The validation of satellite soil moisture products can be very challenging, due to the different spatial scales of in situ measurements and satellite data. Some papers present validation studies to quantify soil moisture uncertainties. On the other hand, soil moisture downscaling schemes and new methods for soil moisture retrieval from GPS are also addressed by some contributions. Soil moisture data are used in fields like agriculture, hydrology, and climate sciences. Several studies explore the use of soil moisture data for hydrological application such as runoff prediction.
\end{abstract}

Keywords: soil moisture; remote sensing; retrieval algorithms; uncertainties; validations; applications

\section{Introduction}

Soil moisture is an essential variable in the earth system, as it influences the exchange of water, energy and carbon fluxes between the land surface and the atmosphere. It plays important roles in various processes and feedback loops within the earth system [1-4]. Soil moisture can be measured by instruments in the field [5] or estimated by remote sensing techniques [1]. With the advances in earth observation technology, the field of remote sensing of soil moisture has expanded greatly in the past decades [6]. Observations from both microwave and optical/thermal infrared sensors have been successfully used to retrieve surface soil moisture [7-9]. In particular, soil moisture retrieval from microwave observations has been highly advanced and several global soil moisture products have been produced [10,11], such as the Advanced Microwave Scanning Radiometer-EOS (AMSR-E) [12], the advanced scatterometer (ASCAT) [13], the Soil Moisture and Ocean Salinity (SMOS) [14,15], the Soil Moisture Active Passive (SMAP) [16], and the European Space Agency's Climate Change Initiative (ESA CCI) soil moisture products $[17,18]$. Extensive validation studies, either through direct comparison against in-situ measurements, or intercomparison among different remotely sensed products, have been conducted to quantify the accuracy of these soil moisture products [19-23]. In addition, the applications of these products have also been widely explored in many fields like agriculture, hydrology, and climate sciences [24-27]. 
Nevertheless, there are still potentials to improve the retrieval algorithms, and open scientific questions on validation and application of the remotely sensed products. In addition, there is strong need to develop high spatial and temporal resolution soil moisture products [28]. Several new satellite missions such as Sentinel-1 provide the opportunity for the estimation of soil moisture at high temporal and spatial resolution. On the other hand, new approaches are required to improve the spatial and temporal resolutions of the existing soil moisture products, such as the synergy of both microwave and optical/thermal soil moisture products. Therefore, this special issue aims to discuss the current state-of-the-art in soil moisture remote sensing, including recent advances in retrieval algorithms, validation, and applications of satellite-based soil moisture products.

\section{Summary of the Special Issue}

This special issue contains 8 well-written papers, which cover a range of topics in remote sensing of soil moisture such as retrieval algorithms, validation, uncertainty assessment, spatial downscaling and applications of remotely sensed soil moisture. A brief overview of these contributions is summarized as follows.

With the use of a large range of Synthetic Aperture Radar (SAR) and in situ measurements, Choker, et al. [29] evaluated the most commonly used backscattering models including Oh, Dubois, Integral Equation Model (IEM) and Advanced Integral Equation Model (AIEM). Their results highlight the best performance of a modified IEM model by Baghdadi, et al. [30]. Since the high-resolution Sentinel-1A and -1B SAR data are already available for the scientific community, the results presented by Choker, et al. [29] will provide a good reference for estimating soil moisture using these Sentinel-1 SAR data.

In addition to the estimation of soil moisture from microwave data, some studies exploit the feasibility of estimating soil moisture at high spatial resolution from optical/thermal satellite observations. For example, Alexandridis, et al. [31] applied a simple approach to estimate root zone soil moisture based on remotely sensed energy balance fluxes and ancillary soil and meteorology data. Without the need of microwave data, the study mainly relies on the moderate resolution imaging spectroradiometer (MODIS) optical and thermal band data. With the use of Landsat 7 data and weather data, Torres-Rua, et al. [32] estimated surface soil moisture using a Bayesian machine learning approach (Relevance Vector Machine), which identifies and relates the soil moisture to potential predictors such as vegetation index, energy balance products by means of stratified cross-validation and forward variable selection. They managed to obtain surface soil moisture. Both studies show the potential of estimating high spatial resolution soil moisture with optical/thermal band data. The research in this direction will shed a light on the fusion of microwave and optical/thermal data to obtain soil moisture at both high temporal and spatial resolutions.

In terms of new soil moisture retrieval technique, Koch, et al. [33] developed a new method to retrieve soil moisture from measurements of Global Positioning System (GPS) sensors. The proposed approach is based on GPS signal (L1-band) strength variations due to variations in the dielectric constant of the soil. As the GPS signal can be received globally, the proposed method could be used to establish soil moisture measurement networks over different regions of the world.

Ray, et al. [34] evaluated four remotely sensed soil moisture products, derived from Advanced Microwave Scanning Radiometer-Earth (AMSR-E), Soil Moisture Ocean Salinity (SMOS), AMSR2 and Soil Moisture Active Passive (SMAP), with in situ measurements over the state of Texas in the United States. The evaluation results highlight the best performance of SMAP product among others.

In order to improve the spatial resolution of the Global Land Data Assimilation System (GLDAS) soil moisture product, Park, et al. [35] proposed a soil moisture downscaling approach by the use of machine learning with different remote sensing products, including soil moisture from AMSR2 and ASCAT, NDVI, LST, and land cover from MODIS, and a digital elevation model from Shuttle Radar Topography Mission (SRTM). The downscaled $1 \mathrm{~km}$ soil moisture product in East Asia may provide valuable information for hydrological and agricultural applications. 
Finally, two papers focused on the applications of remotely sensed soil moisture. Shin, et al. [36] attempted to estimate the soil hydraulic properties from remotely sensed Soil moisture. The developed dynamic ground water (DGW) data assimilation approach can help to improve the accuracy of root-zone soil moisture estimates. The paper by Sunwoo and Choi [37] provided an initial wetness condition (IWC) framework, which adopts remotely sensed soil moisture (ASCAT) to provide a more accurate runoff prediction. The proposed framework may facilitate the runoff prediction particularly over data-sparse regions.

\section{Conclusions}

Much progress has been made in remote sensing of soil moisture in the past decades. This special issue summarizes the current state-of-the-art in soil moisture remote sensing, including algorithm development, validation, uncertainty assessment, and applications of remotely sensed soil moisture products. Some papers exploit the use of both microwave and thermal infrared data for the estimation of soil moisture. Several contributions quantify the soil moisture uncertainties through validation studies. There are also studies focusing on the improvement of the soil moisture spatial resolution and retrieval of soil moisture from GPS. In addition, some papers address the use of soil moisture in hydrological applications such as runoff prediction. Based on the analysis of these papers that are published in this special issue, the following points are concluded to represent the major requirements for the future research in remote sensing of soil moisture.

Improve the accuracy of the retrieved soil moisture: on one hand, retrieval methods still need to be improved to minimize the uncertainties. On the other hand, new techniques for measuring soil moisture, new methods for up-scaling point scale soil moisture and new validation schemes need to be developed to resolve the scale mismatch problem during the validation of remotely sensed soil moisture product.

Generate long-term high-resolution soil moisture products: there is a need to develop models and algorithms that combine multiple datasets (coarse/high resolution soil moisture, optical/thermal data, in situ measurements) to generate long-term high spatial and temporal resolution soil moisture datasets.

Promote the applications of the remotely sensed soil moisture products: near surface soil moisture has great potential to be used in many applications such as agriculture management, hydrology, weather and climate prediction. Relevant data assimilation and modeling schemes need to be developed to promote these applications. Additionally, new schemes for estimation of root zone soil moisture need to be developed due to the requirements for root zone soil moisture by many applications.

Maintain the current operational satellite-based soil moisture products: in order to keep the consistency of the current operational soil moisture products, there is a need to support the maintenance and continuous of these operational products.

Acknowledgments: We are grateful to all authors for their high-quality contributions to this special issue. We also thank the expert reviewers for devoting their time and efforts to review the submitted manuscripts. We finally highly appreciate the Water Editorial office for their great assistance during the whole review processes.

Conflicts of Interest: The authors declare no conflict of interest.

\section{References}

1. Ochsner, T.E.; Cosh, M.H.; Cuenca, R.H.; Dorigo, W.A.; Draper, C.S.; Hagimoto, Y.; Kerr, Y.H.; Njoku, E.G.; Small, E.E.; Zreda, M. State of the art in large-scale soil moisture monitoring. Soil Sci. Soc. Am. J. 2013, 77, 1888-1919. [CrossRef]

2. Mohanty, B.P.; Cosh, M.H.; Lakshmi, V.; Montzka, C. Soil moisture remote sensing: State-of-the-science. Vadose Zone J. 2017, 16. [CrossRef]

3. Peng, J.; Loew, A.; Zhang, S.; Wang, J.; Niesel, J. Spatial downscaling of satellite soil moisture data using a vegetation temperature condition index. IEEE Trans. Geosci. Remote Sens. 2016, 54, 558-566. [CrossRef] 
4. $\quad$ Legates, D.R.; Mahmood, R.; Levia, D.F.; DeLiberty, T.L.; Quiring, S.M.; Houser, C.; Nelson, F.E. Soil moisture: A central and unifying theme in physical geography. Prog. Phys. Geogr. 2011, 35, 65-86.

5. Romano, N. Soil moisture at local scale: Measurements and simulations. J. Hydrol. 2014, 516, 6-20. [CrossRef]

6. Seneviratne, S.I.; Corti, T.; Davin, E.L.; Hirschi, M.; Jaeger, E.B.; Lehner, I.; Orlowsky, B.; Teuling, A.J. Investigating soil moisture-climate interactions in a changing climate: A review. Earth-Sci. Rev. 2010, 99, 125-161. [CrossRef]

7. Peng, J.; Niesel, J.; Loew, A. Evaluation of soil moisture downscaling using a simple thermal-based proxy-The remedhus network (spain) example. Hydrol. Earth Syst. Sci. 2015, 19, 4765-4782. [CrossRef]

8. Petropoulos, G.P.; Ireland, G.; Barrett, B. Surface soil moisture retrievals from remote sensing: Current status, products \& future trends. Phys. Chem. Earth Parts A/B/C 2015, 83-84, 36-56.

9. Loew, A.; Ludwig, R.; Mauser, W. Derivation of surface soil moisture from envisat asar wide swath and image mode data in agricultural areas. IEEE Trans. Geosci. Remote Sens. 2006, 44, 889-899. [CrossRef]

10. Njoku, E.G.; Jackson, T.J.; Lakshmi, V.; Chan, T.K.; Nghiem, S.V. Soil moisture retrieval from amsr-e. IEEE Trans. Geosci. Remote Sens. 2003, 41, 215-229. [CrossRef]

11. Wagner, W.; Blöschl, G.; Pampaloni, P.; Calvet, J.-C.; Bizzarri, B.; Wigneron, J.-P.; Kerr, Y. Operational readiness of microwave remote sensing of soil moisture for hydrologic applications. Hydrol. Res. 2007, 38, 1-20. [CrossRef]

12. Owe, M.; de Jeu, R.; Holmes, T. Multisensor historical climatology of satellite-derived global land surface moisture. J. Geophys. Res. Earth Surf. 2008, 113, F01002. [CrossRef]

13. Naeimi, V.; Scipal, K.; Bartalis, Z.; Hasenauer, S.; Wagner, W. An improved soil moisture retrieval algorithm for ers and metop scatterometer observations. IEEE Trans. Geosci. Remote Sens. 2009, 47, 1999-2013. [CrossRef]

14. Jacquette, E.; Al Bitar, A.; Mialon, A.; Kerr, Y.; Quesney, A.; Cabot, F.; Richaume, P. SMOS CATDS level 3 global products over land. Proceedings of Remote Sensing for Agriculture, Ecosystems, and Hydrology XII, Toulouse, France, 20 September 2010; Volumn 7824, pp. 78240-78246.

15. Kerr, Y.H.; Waldteufel, P.; Wigneron, J.-P.; Martinuzzi, J.; Font, J.; Berger, M. Soil moisture retrieval from space: The soil moisture and ocean salinity (SMOS) mission. IEEE Trans. Geosci. Remote Sens. 2001, 39, 1729-1735. [CrossRef]

16. Entekhabi, D.; Njoku, E.G.; Neill, P.E.; Kellogg, K.H.; Crow, W.T.; Edelstein, W.N.; Entin, J.K.; Goodman, S.D.; Jackson, T.J.; Johnson, J. The soil moisture active passive (SMAP) mission. Proc. IEEE 2010, 98, 704-716. [CrossRef]

17. Liu, Y.Y.; Parinussa, R.M.; Dorigo, W.A.; De Jeu, R.A.M.; Wagner, W.; van Dijk, A.I.J.M.; McCabe, M.F.; Evans, J.P. Developing an improved soil moisture dataset by blending passive and active microwave satellite-based retrievals. Hydrol. Earth Syst. Sci. 2011, 15, 425-436. [CrossRef]

18. Wagner, W.; Dorigo, W.; de Jeu, R.; Fernandez, D.; Benveniste, J.; Haas, E.; Ertl, M. Fusion of active and passive microwave observations to create an essential climate variable data record on soil moisture. ISPRS Ann. Photogramm. Remote Sens. Spat. Inf. Sci. 2012, 1-7, 315-321.

19. Albergel, C.; De Rosnay, P.; Gruhier, C.; Muñoz-Sabater, J.; Hasenauer, S.; Isaksen, L.; Kerr, Y.; Wagner, W. Evaluation of remotely sensed and modelled soil moisture products using global ground-based in situ observations. Remote Sens. Environ. 2012, 118, 215-226. [CrossRef]

20. Dorigo, W.A.; Gruber, A.; De Jeu, R.; Wagner, W.; Stacke, T.; Loew, A.; Albergel, C.; Brocca, L.; Chung, D.; Parinussa, R. Evaluation of the esa cci soil moisture product using ground-based observations. Remote Sens. Environ. 2015, 162, 380-395. [CrossRef]

21. Jackson, T.J.; Bindlish, R.; Cosh, M.H.; Zhao, T.; Starks, P.J.; Bosch, D.D.; Seyfried, M.; Moran, M.S.; Goodrich, D.C.; Kerr, Y.H. Validation of soil moisture and ocean salinity (smos) soil moisture over watershed networks in the us. IEEE Trans. Geosci. Remote Sens. 2012, 50, 1530-1543. [CrossRef]

22. Peng, J.; Niesel, J.; Loew, A.; Zhang, S.; Wang, J. Evaluation of satellite and reanalysis soil moisture products over southwest china using ground-based measurements. Remote Sens. 2015, 7, 15729-15747. [CrossRef]

23. Sanchez, N.; Martínez-Fernández, J.; Scaini, A.; Perez-Gutierrez, C. Validation of the smos 12 soil moisture data in the remedhus network (spain). IEEE Trans. Geosci. Remote Sens. 2012, 50, 1602-1611. [CrossRef]

24. AghaKouchak, A.; Farahmand, A.; Melton, F.S.; Teixeira, J.; Anderson, M.C.; Wardlow, B.D.; Hain, C.R. Remote sensing of drought: Progress, challenges and opportunities. Rev. Geophys. 2015, 53, 452-480. [CrossRef] 
25. Loew, A.; Stacke, T.; Dorigo, W.; de Jeu, R.; Hagemann, S. Potential and limitations of multidecadal satellite soil moisture observations for selected climate model evaluation studies. Hydrol. Earth Sys. Sci. 2013, 17, 3523-3542. [CrossRef]

26. Brocca, L.; Crow, W.T.; Ciabatta, L.; Massari, C.; de Rosnay, P.; Enenkel, M.; Hahn, S.; Amarnath, G.; Camici, S.; Tarpanelli, A.; et al. A review of the applications of ascat soil moisture products. IEEE J. Sel. Top. Appl. Earth Obs. Remote Sens. 2017, 5, 2285-2306. [CrossRef]

27. Li, Y.; Grimaldi, S.; Walker, J.; Pauwels, V. Application of remote sensing data to constrain operational rainfall-driven flood forecasting: A review. Remote Sens. 2016, 8, 456. [CrossRef]

28. Peng, J.; Loew, A.; Merlin, O.; Verhoest, N.E.C. A review of spatial downscaling of satellite remotely sensed soil moisture. Rev. Geophys. 2017. [CrossRef]

29. Choker, M.; Baghdadi, N.; Zribi, M.; El Hajj, M.; Paloscia, S.; Verhoest, N.; Lievens, H.; Mattia, F. Evaluation of the oh, dubois and iem backscatter models using a large dataset of sar data and experimental soil measurements. Water 2017, 9, 38. [CrossRef]

30. Baghdadi, N.; King, C.; Chanzy, A.; Wigneron, J.P. An empirical calibration of the integral equation model based on sar data, soil moisture and surface roughness measurement over bare soils. Int. J. Remote Sens. 2002, 23, 4325-4340. [CrossRef]

31. Alexandridis, T.; Cherif, I.; Bilas, G.; Almeida, W.; Hartanto, I.; van Andel, S.; Araujo, A. Spatial and temporal distribution of soil moisture at the catchment scale using remotely-sensed energy fluxes. Water 2016, 8, 32. [CrossRef]

32. Torres-Rua, A.; Ticlavilca, A.; Bachour, R.; McKee, M. Estimation of surface soil moisture in irrigated lands by assimilation of landsat vegetation indices, surface energy balance products, and relevance vector machines. Water 2016, 8, 167. [CrossRef]

33. Koch, F.; Schlenz, F.; Prasch, M.; Appel, F.; Ruf, T.; Mauser, W. Soil moisture retrieval based on GPS signal strength attenuation. Water 2016, 8, 276. [CrossRef]

34. Ray, R.; Fares, A.; He, Y.; Temimi, M. Evaluation and inter-comparison of satellite soil moisture products using in situ observations over Texas, U.S. Water 2017, 9, 372. [CrossRef]

35. Park, S.; Park, S.; Im, J.; Rhee, J.; Shin, J.; Park, J. Downscaling gldas soil moisture data in east asia through fusion of multi-sensors by optimizing modified regression trees. Water 2017, 9, 332. [CrossRef]

36. Shin, Y.; Lim, K.; Park, K.; Jung, Y. Development of dynamic ground water data assimilation for quantifying soil hydraulic properties from remotely sensed soil moisture. Water 2016, 8, 311. [CrossRef]

37. Sunwoo, W.; Choi, M. Robust initial wetness condition framework of an event-based rainfall-runoff model using remotely sensed soil moisture. Water 2017, 9, 77. [CrossRef] 